\title{
The Climate Finance Conundrum
}

\author{
Anis Chowdhury ${ }^{1} \cdot$ Jomo Kwame Sundaram ${ }^{2}$
}

Published online: 15 February 2022

(c) Society for International Development 2022

\begin{abstract}
International climate finance is key to managing overall climate risk with many developing countries' climate plans and actions are conditional on getting the necessary financial support. Unsurprisingly, helping fund poorer countries to address climate change is one of the most contentious subjects in climate politics. This article examines the state of play and offers some suggestions to unblock the impasse.
\end{abstract}

Keywords Green climate fund $\cdot$ Multilateral development banks $\cdot$ Mitigation $\cdot$ Adaptation $\cdot$ Losses and damages $\cdot$ Carbon trading $\cdot$ Climate injustice $\cdot$ Special drawing rights $\cdot$ Quantitative easing

Climate finance refers to the local, national, or transnational financing that supports mitigation and adaptation actions to address climate change, according to the UN Framework Convention on Climate Change (UNFCCC). ${ }^{1}$ It can be drawn from public, private, and alternative sources of financing.

Climate finance is needed for mitigation, adaptation, and 'losses and damages' (L\&D). Mitigating global warming requires large-scale investments to significantly reduce greenhouse gas (GHG) emissions and reduce the adverse impacts of changing climate. Adaptation requires significant financial resources for adjusting to such adverse effects. Equally large sums are also needed to repair and recover from L\&D. Such financial needs are beyond the capacity of many developing countries.

Ironically, the least-resourced developing countries have contributed least to GHG emissions. 'The contribution of low-income developing countries ... to atmospheric greenhouse gas concentrations is negligible, both in absolute terms and on a per capita basis' (IMF 2017: 119). Developed nations account for two-thirds of cumulative emissions compared to only $3 \%$ from Africa (UNCTAD 2021).

Anis Chowdhury

anis.z.chowdhury@gmail.com

Jomo Kwame Sundaram

jomoks@yahoo.com

1 School of Business, Western Sydney University, Sydney, Australia

2 Khazanah Research Institute, Kuala Lumpur, Malaysia
Furthermore, carbon emissions by the wealthiest $1 \%$ of the world's population were more than twice those of the bottom half between 1990 and 2015 (UNCTAD 2021)! It is indeed a 'cruel irony' that those far less responsible for global warming 'are being made to pay a larger share of the price' (Bassetti 2019).

Unsurprisingly, the International Monetary Fund (IMF)'s 2017 World Economic Outlook shows that the brunt of these adverse consequences is borne by those who can least afford it - the low-income countries (LICs). Thus, it argues, 'the international community must play a key role in supporting these countries' efforts to cope with climate change - a global threat to which they have contributed little' (IMF 2017: 117).

The principle of 'common but differentiated responsibility and respective capabilities' recognizes these disparities and inequities. The contribution of these countries to climate change and their financial capacity to mitigate it and to cope with its consequences vary enormously. The UNFCCC, the Kyoto Protocol (KP) and the Paris Agreement (PA) call for financial assistance from Parties with more financial resources to those less well endowed, but more vulnerable to the impacts of climate change.

Climate finance therefore necessarily involves issues of justice and equity, with richer nations having the responsibility to help poorer nations' efforts to cut GHG emissions, adjust to adverse climate impacts, and recover from L\&D. This argument was acknowledged by the UK prime minister

\footnotetext{
$\overline{1}$ https://unfecc.int/topics/climate-finance/the-big-picture/introducti
} on-to-climate-finance accessed 10 January 2022. 
Boris Johnson in a speech at the UN in September 2021, just two months before COP26 in Glasgow.

Richer nations have reaped the benefits of untrammelled pollution for generations, often at the expense of developing countries. As those countries now try to grow their economies in a clean, green, and sustainable way we have a duty to support them in doing so - with our technology, with our expertise and with the money we have promised. ${ }^{2}$

In short, international climate finance is key to managing overall climate risk and many developing countries' climate plans and action are conditional on getting the necessary financial support. Unsurprisingly, helping fund poorer countries to address climate change is one of the most contentious subjects in climate politics.

At COP15 held in Copenhagen in 2009, wealthy nations pledged to collectively mobilize US $\$ 100 \mathrm{bn}$ annually for climate finance by 2020 to help vulnerable nations deal with climate change. The commitment was formalized at the 2010 Cancún COP10 and reaffirmed as a key element of the 2015 PA. But in December 2020, well before the 2021 Glasgow COP26, the UN Independent Expert Group on Climate Finance (UN-IEGCF 2020: 7) concluded that'the only realistic scenarios are those in which the $\$ 100$ billion target is not reached this year' (referring to 2020).

Despite alleged double counting and other methodological flaws, the recent report from the Organisation for Economic Cooperation and Development (OECD 2021) shows that total climate finance reached only US $\$ 79.9 \mathrm{bn}$ in 2019. In presenting the report, the OECD Secretary-General observed, 'The limited progress in overall climate finance volumes between 2018 and 2019 is disappointing, particularly ahead of COP26. While appropriately verified data for 2020 will not be available until early next year, it is clear that climate finance will remain well short of its target'.

Therefore, climate finance was 'the elephant in the room at COP26', and a central pillar of the negotiations (Mitchell 2021). Rich and less-resourced parties contested the definitions, measurements, and projections of climate finance while least developed countries (LDCs) and small island developing states (SIDS) expressed disappointment, especially at the lack of progress on a dedicated fund facility for L\&D due to climate change.

The rest of this article provides a brief overview of the state of climate finance, considers relevant key climate

\footnotetext{
2 https://www.gov.uk/government/news/pm-calls-on-richest-count ries-to-meet-100-billion-climate-pledge accessed 11 January 2022.

3 https://www.oecd.org/newsroom/statement-from-oecd-secretarygeneral-mathias-cormann-on-climate-finance-in-2019.htm accessed 10 January 2022.
}

finance outcomes at COP26 in Glasgow, and proposes ways to significantly enhance the availability to poorer countries of finance for climate mitigation and adaptation.

\section{Climate Finance Mess}

Tracking climate finance is difficult because there is no clear universal definition of what counts. The UNFCCC does not have an operational definition for measuring and recording climate finance flows. After reviewing varied climate finance definitions used by data collectors and aggregators, the UNFCCC's Standing Committee on Finance (UNFCCCSCF 2014: 5) offered the following operational definition: 'Climate finance aims at reducing emissions and enhancing sinks of greenhouse gases and aims at reducing the vulnerability of, and maintaining and increasing the resilience of, human and ecological systems to negative climate change impacts'.

But this too is very broad, leaving room for ambiguity. Unsurprisingly, international climate finance figures are widely contested (Weikmans and Roberts 2019). The World Resources Institute (WRI) reminds us that the lack of clarity in climate finance reporting means the numbers need to be treated with caution (Bos and Thwaites 2021).

\section{Inadequate Climate Finance}

The Climate Policy Initiative (CPI)'s Global Landscape of Climate Finance 2021 provides the most comprehensive overview of global 'climate-related primary investment' or climate finance. It includes all sources of climate finance - private, public, national and development finance institutions (DFIs), including multilateral development banks (MDBs) - and all instruments - grants, low-cost project debt, ${ }^{4}$ project-level market rate debt, project-level equity, debts, balance sheet financing ${ }^{5}$ and equity. It also covers funds for mitigation, adaption and mixed-uses, as well as sectoral breakdowns. Its key findings are:

- Total climate finance steadily increased over the last decade from US\$364bn in 2011-12 to US\$632bn in 2019-20, but increases have slowed since 2017-18.

- An increase of at least $590 \%$ in annual climate finance is required to meet internationally agreed climate objectives by 2030 , and to avoid the most dangerous impacts of climate change.

- Adaptation finance continues to lag. Despite increasing to US\$46bn in 2019-20 from US\$30bn in 2017-18, total

\footnotetext{
${ }^{4}$ By using project cash flows to make repayments.

${ }^{5}$ With funding from the assets of the recipient institution or entity.
} 
adaptation finance remains far below the scale necessary to respond adequately to existing and future climate change.

- Mitigation investment in hard-to-decarbonize sectors remains low, partly attributed to limited data availability mainly due to confidentiality restrictions.

- The public sector continues to provide almost all adaptation finance, with its share rising in development finance climate portfolios. However, adaptation finance represented only $14 \%$ of total public finance, while there were almost no private investments in adaptation.

- Public climate finance increased by $7 \%$ from 2017 to 18 , remaining largely stable at $51 \%$ (US $\$ 321 \mathrm{bn}$ ) of the total. Meanwhile, private climate investment increased by $13 \%$ from 2017 to 18 , to US\$310bn. DFIs continued to deliver most $(68 \%)$ of public finance, while corporations (mainly commercial financial institutions) accounted for $40 \%$ of private climate finance.

- Most climate finance - $61 \%$ (US\$384bn) - was raised as debt, of which only $12 \%$ (US $\$ 47 \mathrm{bn}$ ) was low-cost or concessional. Equity investments - the next largest category after debt - came to $33 \%$ of total climate finance. Grant finance was a paltry US\$36bn, or $6 \%$ of the total.

- Three-quarters of global climate investments were for East Asia and the Pacific, Western Europe, and North America, while remaining regions received less than a quarter, revealing gross inequity marginalizing Africa, Latin America and the Caribbean SIDS. Even in East Asia and the Pacific, which accounted for almost half (US\$292bn) in 2019-20, South Pacific SIDS received very little as $81 \%$ of the investments were in China.

\section{Pledge Unmet}

Some worrying trends have been widely acknowledged (Bos and Thwaites 2021). First, most developed countries are not contributing their 'fair share' to meeting the US\$100bn annual goal. Each country's 'fair share' is based on a composite index using gross national income (GNI) and population for 2020, and recent cumulative $\mathrm{CO}_{2}$ emissions during 1990-2019 (Colenbrander et al. 2021). ${ }^{6}$ In 2018, the US, Australia, Canada, Spain, Greece, New Zealand and Portugal provided less than $25 \%$ of their 'fair shares'. The

\footnotetext{
6 The principle of 'common but differentiated responsibility and respective capabilities' has long been at the heart of the UNFCCC. While it is difficult to hold developed countries collectively accountable for meeting the target, the climate accords do not determine responsibility among developed countries for their historical GHG emissions. Also, individual governments have not publicly indicated what they consider to be a 'fair share' formula for meeting the US \$100bn annual target. Instead, $2020 \mathrm{GNI}$ and population size have been taken together to estimate crude proxies for financial capacities and related fair shares for meeting the target.
}

contributions of the UK, Luxembourg, Austria, Iceland, Ireland and Italy also fell short of their 'fair shares' by 25 to $50 \%$.

Second, the varying 'quality' of climate finance and reporting ambiguities frustrate easy comparison. For example, France, Japan and Germany contribute 75 to $100 \%$ of their 'fair shares', but provide most of their finance in loans, which must be repaid. Among countries contributing 50 to $75 \%$ of their 'fair shares', the majority provided most of their finance as grants.

Third, adaptation financing is well short despite the PA's professed aim to balance climate finance between mitigation and adaptation. Recognizing this glaring shortfall and the absence of resources to compensate for $\mathrm{L} \& \mathrm{D}$, many climatevulnerable countries and the UN Secretary-General have called on developed countries to balance climate finance equally. ${ }^{7}$

Fourth, little finance flows through Multilateral Climate Funds (MCFs) like the Green Climate Fund (GCF) and the Adaptation Fund (AF), which were mandated by the PA to finance climate action. Most developed countries channel their largest climate finance contributions through MDBs, such as the World Bank, African Development Bank and Asian Development Bank, in which they are significant shareholders with more influence. MCFs, e.g., the GCF and the AF, were mandated by the PA to finance climate action. But little finance flows through them as MCFs give developing countries a much greater say in climate finance governance, enabling them to directly access funding. Instead, most rich countries choose to channel their contributions through the MDBs where they have more influence. Unsurprisingly, MDB finance favours private sector 'market solutions', often with onerous conditionalities.

The pandemic has made things worse, according to research on 17 developing countries (Alayza and Caldwell 2021). Some nations saw a decrease in their climate budgets or delays in climate-related project implementation, having to respond to the high socio-economic and health costs of the pandemic. Facing pandemic disruption, developing countries not only had to turn to debt financing, but also to prioritize spending to cope with pandemic crises.

For example, in Honduras, loans for the health and social sectors were prioritized over funding a climate resilience project with the GCF and Inter-American Development Bank. South Africa's food security programme saw a $46 \%$ reduction in expenditure, contributing to a significant loss in adaptation spending. In Kenya, the Energy, Infrastructure

\footnotetext{
7 https://www.v-20.org/activities/ministerial/1st-climate-vulnerablesfinance-summit-communique accessed 12 January 2022; https://unfccc.int/news/antonio-guterres-50-of-all-climate-finance-needed-foradaptation accessed 12 January 2022.
} 
and Information-Communication-Technology Department saw a $23 \%$ reduction in allocations. Some paltry increases in climate finance in a few countries during 2019-20 are misleading as they often were due to counting non-climaterelated activities, e.g., in Mexico.

\section{Improvement Needed}

For the UN Secretary-General, '[o]ver the past 25 years, the richest $10 \%$ of the global population has been responsible for more than half of all carbon emissions, and the poorest $50 \%$ were responsible for just $7 \%$ of emissions ${ }^{8}{ }^{8}$ The World Bank estimates that, if left unchecked, climate change will condemn 132 million more people into poverty over the next decade, while displacing more than 216 million from their homes and land by $2050 .^{9}$

Therefore, rich countries - most responsible for GHG emissions and global warming - should be much more ambitious and need to do much more than their US $\$ 100$ bn yearly pledge, reluctantly reiterated after a dozen years of massive shortfalls. Financing terms should also be far more generous than is currently the case, and prioritize adaptation, especially for the poorest countries most at risk.

Climate finance has also been beset by waste, corruption, deceit, ambiguity, and inefficiency. Also, there has been little impact measurement. For this to improve, donor countries and MDBs have primary responsibilities in this regard. However, challenges such as 'wastage' and 'corruption' must not become excuses for reneging on promised finance or policy reforms skewed to serving profit-seeking corporations.

\section{COP26 Failure}

Climate finance needs much more funding for mitigation, adaptation, and L\&D, with each needing significant resources. The Glasgow Climate Pact noted 'with deep regret that the goal of developed country Parties to mobilize jointly US $\$ 100$ billion per year by 2020 in the context of meaningful mitigation actions and transparency on implementation has not yet been met'. There was also no commitment at COP26 to help the most vulnerable, but least resourced countries' efforts to deal with L\&D.

\footnotetext{
8 https://www.sei.org/wp-content/uploads/2021/05/seij8574-annualreport-2020-210521-web.pdf accessed 12 January 2022.

9 https://www.worldbank.org/en/news/feature/2021/10/31/cop26-theworld-is-watching accessed 12 January 2022.
}

In late October 2021, the UK COP26 Presidency published a Climate Finance Delivery Plan, ${ }^{10}$ based on contested OECD figures. It projected a climate finance trajectory from 2021 to 2025 . However, the vague US\$100bn target and lack of accountability mechanisms were both left unaddressed.

With details murky on whether and how the target would be met, the Delivery Plan implies the financing goal will 'likely' be achieved by 2023 . Unsurprisingly, the OECD estimates - upon which this new deadline is based - use the 'most generous interpretation of the finance target possible' (Mitchell 2021). Thus, Oxfam assessed total climate finance for 2017-18 at US\$19-22.5bn - roughly US\$60bn below OECD's 2018 estimate! This suggests that donors will continue to miss the US $\$ 100$ bn yearly target through 2025 (Oxfam 2021).

\section{Climate Finance Disappointments}

Rich countries offered no guarantees regarding the nature of climate finance in the years ahead. For example, despite the emphasis in the Glasgow Climate Pact and Delivery Plan on the need for concessional funding, no firm commitment on the matter was forthcoming. This will probably mean that low- and middle-income countries (LMICs) will continue to receive much of their climate finance as loans (Johnson and West 2021).

According to the OECD, loans represented $71 \%$ of public climate finance in 2019. Over-reliance on loans increases LMICs' debt dependence, exaggerating the 'true value' of climate finance mobilized, since loan repayments and interest payments should be subtracted from total financing figures. Moreover, loans for LMICs are generally much more expensive than for developed countries. Hence, climaterelated disasters strike in such LMICs will be followed by spikes in national borrowing, pushing them into what may be termed 'climate debt traps'. The 'quality of climate finance' includes deployment issues, e.g., reducing fragmentation of international resources, and investing to accelerate the transition to affordable renewable energy. The only noteworthy announcement has been an initiative by a group of donor governments working with South Africa to fund US $\$ 8.5 \mathrm{bn}$ to accelerate a transition from coal. ${ }^{11}$

${ }^{10}$ Climate Finance Delivery Plan: Meeting the US $\$ 100$ billion Goal. https://ukcop26.org/wp-content/uploads/2021/10/Climate-FinanceDelivery-Plan-1.pdf accessed 11 January 2022.

11 The US, the UK, the EU, France, Germany. Heavily reliant on ageing coal-fired power stations for electricity, and with more than 90,000 employed in coal mines in 2020, South Africa is the world's 12th biggest emitter of GHGs. South Africa has pledged to cut GHG emissions by 2030 in its updated submission on its intended contribution to global efforts. South African President Cyril Ramaphosa said that the agreement marked a 'watershed moment' for South Africa and the world, while European Commission President von der Leyen 


\section{Carbon Offsets Shell Game}

GHG emissions offsetting enables countries and companies to continue emitting such gases instead of cutting them. By buying offsets from others who have done so, they claim their emissions have been 'cancelled out'. Carbon offsets also include polluters funding carbon absorbing projects such as forest conservation or re-forestation.

However, carbon offset markets have slowed progress on climate action in the rich North, responsible for two-thirds of cumulative emissions. Achieving 'net-zero' via offsets markets has become a major distraction to greater progress on climate action. Thus, 'net-zero' implies commitment to a zero-sum game, at best maintaining atmospheric GHG levels. Instead, climate mitigation action requires accelerating GHG or carbon reduction, i.e., being 'net-negative', not just net-zero.

Six years after the 2015 COP, after difficult, protracted negotiations, Article 6 on carbon trading was the last of the PA's 29 Articles agreed to (Spring and Abnett 2021). Article 6 seeks to unify carbon offset trading standards to minimize 'double counting'. Article 6 does not actually stop emissions of carbon dioxide $\left(\mathrm{CO}_{2}\right)$ and other GHGs, but effectively enables not doing so by paying others to cut emissions. In longer term perspective, the KP's Clean Development Mechanism (CDM) also enabled doing likewise.

Such offset markets have long been challenged on many grounds. For example, what is the rationale for paying for emission cuts which would have happened anyway, even without being paid for via the offsets market?

Much scope to game the system also remains. Many ostensible 'carbon offsets' sold as 'carbon credits' do not actually involve removing additional carbon, as claimed. Less than $5 \%$ of all offsets reduce $\mathrm{CO}_{2}$ in the atmosphere. ${ }^{12}$ A 2016 European Commission study of CDM offset projects found $85 \%$ had no environmental benefits. ${ }^{13}$

Prices were kept low by ramping up the supply of offsets. Often buying cheap in bulk, big polluters pay too little for carbon credits to incentivize them to switch to renewable energy (The Economist 2020). Averaging only US\$3 per tonne of $\mathrm{CO}_{2}$ in 2018 , they can hardly be expected to accelerate desired energy transitions. Meanwhile, J.P. Morgan, Disney and BlackRock have all bought millions of dollars of

\footnotetext{
Footnote 11 (continued)

noted that the 'just energy transition partnership' could provide a blueprint for cooperation with other countries (Mason et al. 2021).

$12 \mathrm{https}: / /$ climatenewsaustralia.com/the-vast-majority-of-carbon-offse ts-do-not-help-to-combat-climate-change-ext-visuals/ accessed 12 January 2022.

13 https://www.transportenvironment.org/discover/eu-publishesdamning-report-emissions-offsets-calling-question-eus-aviation-clima te-strategy/ accessed 12 January 2022.
}

offsets to protect forests not even under threat (Elgin 2020). The Economist (2020) has described carbon offsets as "cheap cheats'. One CEO acknowledged its offset - buying into a Tanzania forestry programme - involved 'cheating. ${ }^{14}$ Meanwhile, energy-intensive companies collude and lobby against high carbon prices, arguing they damage competitiveness (InfluenceMap 2019; Clarke and Barratt 2021, EdgecliffeJohnson and Holloger 2021).

Thus, such arrangements enable wealthy nations and companies to avoid reducing fossil fuel use at little cost. A month before COP26, a broad coalition of over 170 NGOs, advocacy groups, and grassroots organizations released a statement, declaring that carbon offset programmes are false solutions that will not solve the climate crisis. ${ }^{15}$ Furthermore, the expansion of carbon credits puts pressure on indigenous and forest communities for land needed by offset projects.

Touting market solutions, the World Bank (2021) has noted a recent surge in demand from major financial actors, including Goldman Sachs, Morgan Stanley and Lansdowne Partners. But much goes to profits from arbitrage, speculation, or trading for third parties - not decarbonization or net-zero.

Even Larry Fink - CEO of Blackrock, the world's largest asset manager - is sceptical, 'We are lying to ourselves if we think we can do it just by conveniently asking banks and financial service companies, public companies, to conform to TCFD reporting. ${ }^{16} \mathrm{We}$ are creating the biggest capital arbitrage of our lifetimes' (quoted in Baker 2021: 5).

Just before the COP began in Glasgow, the captains of big finance inaugurated the Glasgow Financial Alliance for Net Zero (GFANZ), representing US $\$ 130$ trillion in assets to accelerate the transition, to a net-zero emissions economy. The GFANZ - chaired by former Bank of England Governor Mark Carney, now UN Special Envoy for Climate Action and Finance - claims to leverage the power of big finance and unlock trillions of dollars to innovatively achieve the PA goal of keeping the temperature rise above pre-industrial levels under $1.5^{\circ} \mathrm{C}$.

Larry Fink (2021) argues for substantially more public subsidy to de-risk private investment in developing economies, while GFANZ members' pledges to substantially

\footnotetext{
14 https://www.smh.com.au/business/companies/it-s-cheating-etihad-ceo-s-frank-admission-on-carbon-offsets-20211118-p599xz.html accessed 12 January 2022.

15 https://amazonwatch.org/news/2021/1006-statement-offsets-dontstop-climate-change accessed 18 January 2022.

16 The Task Force on Climate-related Financial Disclosures (TCFD) was set up in 2015 by the Financial Stability Board (FSB) to develop a framework for a more effective voluntary reporting by companies and other organizations of their climate-related financial investment decisions.
} 
increase their climate finance investments are contingent on 'incentivization'. Incentivization implies privileged access for profit-seeking private investment to large 'bankable' low-risk projects as well as securing 'senior' positions, i.e., prior or first claim in case of bankruptcy or debt restructuring (Tonkonogy 2021). To take additional risk, these large transnational fund managers often compete for the same concessional funding that small national private investors also vie for, e.g., via the GCF. Thus, private funds from GFANZ are only likely to flow to 'bankable projects' and often are not aligned with the needs and priorities of developing countries; hence, they rarely support adaptation, or flow to countries where funds are most needed.

Unsurprisingly, the headline grabbing GFANZ announcement was greeted by skeptical charges of 'greenwashing'. Big businesses are said to be burnishing their green credentials by citing their carbon offset purchases as proof of their contribution to protecting the environment and mitigating global warming. But again, there are no agreed metrics to ensure that portfolios of private investments are aligned with the PA (Baker 2021). Uncharacteristically, the Marshall Islands' climate envoy has urged remaining 'vigilant against greenwashing. ${ }^{17}$

\section{MDBs Disappoint Again}

The role and contribution of MDBs have also been disappointing. Despite their espoused commitment to the PA, the efforts of MDBs at COP26 appeared 'lost in technical details and individual, often one-off initiatives. There were no collective timelines for Paris Alignment announced, no joint commitments on fossil fuel financing' (Tonkonogy 2021: 1).

Unsurprisingly, observers reacted skeptically to the ten major MDBs' Joint Paris Alignment Statement at COP26 on 2 November. Some examples ${ }^{18}$ are quite telling:

'MDBs lack ambition at this COP... This does not reflect the urgency of the task...'

' $\ldots$ after years of stalling the MDBs are now standing in the way of the Paris Agreement rather than aligning with it, [instead of] ... re-focusing their climate finance to serve the most vulnerable communities rather than private sector profits.'

'MDBs are not only not delivering on the Paris goals, they're also actively exploiting loopholes to continue financing fossil fuels.'

\footnotetext{
17 https://www.reuters.com/business/cop/outline-carbon-marketsdeal-emerges-un-climate-summit-2021-11-13/ accessed 11 January 2021.

18 https://bigshiftglobal.org/big-shift-global-reaction-multilateraldevelopment-bank-joint-paris-alignment-statement-cop26 accessed 12 January 2022.
}

'We need to see MDBs adopt a whole-of-institution approach to climate, rather than continuing to offer fossil finance loopholes - loopholes that will end up being sinkholes for MDB clients.'

'... Any MDB plan that claims to be leveraging private climate finance must include an end to policy reforms that make fossil fuels more profitable, such as tax breaks, Public-Private Partnerships, and higher consumer energy tariffs... MDB leveraging of private finance away from climate investments.'

'This statement of 'ambition' by ten MDBs does not contain the words 'oil' and 'gas'... This statement is a travesty of justice.'

Despite the MDBs' Paris alignment pledge, it was noted that 'significant progress will be needed for these banks to meet their commitments by 2023-2024' (McCandless et al. 2021). The MDBs were still a long way away from realizing their commitment throughout their portfolios (Larsen et al. 2018). While the MDBs now claim to align their direct investments with the Paris goals, this effort may be insufficiently ambitious and far from comprehensive. MDBs have also paid little attention before to whether their indirect investments support climate goals. 'Policy loans' - deemed more urgent than project loans in times of crisis - remain another blind spot.

\section{Unmet Pledge Recycled}

Besides the unmet pledge of US\$100bn yearly made in 2009 , there have been other setbacks. For example, little progress has been made in resolving methodological and measurement disputes over climate finance.

The OECD includes both public and private finance, with sources - public/private, grants/loans, export credits, etc. - undifferentiated. Such ambiguity enables double-counting, poor transparency and creative accounting (UN-IEGCF 2020). Some donors count most development aid or official development assistance (ODA), even when not primarily for 'climate action'.

The dispute over which funds are to be considered 'new and additional' has also not been resolved since the UNFCCC was adopted at the Rio Earth Summit in 1992 (Roberts et al. 2021). ODA redesignated as climate finance should therefore be categorized as 'reallocated', rather than 'additional' funding. It is important to acknowledge that poor countries are consequently losing aid for education, health and other purposes. There is also little agreement on how climate finance is spent, who should receive it, criteria for efficacy, or how to make sure it is used effectively.

Developing countries at COP26 wanted a clearer quantified plan, with an agreed accountability and monitoring framework, a roadmap for progress towards the US\$100bn 
yearly target to avoid further delays in implementation, and a more ambitious climate finance goal kicking in after 2025. However, developed countries successfully resisted these efforts. The question of what will happen after 2025 was left open despite the urgent need to agree on a measurable new climate finance target. The need for climate finance is great and fast growing in the face of massive past shortfalls and the rapidly deteriorating climate crisis.

\section{Arbitrary Target Inadequate}

But even if the US\$100bn annual target is finally met, it would be hugely inadequate, even without taking COVID-19 pandemic impacts into account. The US\$100bn target was somewhat arbitrary in the first place, and far short of the needs of developing nations, especially the poorest.

Yet, as European leaders promised this amount before the 2009 COP, it continues to be the reference for governments trying to set a climate finance target. Hence, the gap between countries' climate finance needs and what they received was already widening before the pandemic.

To ensure global warming stays below the PA goal of $1.5^{\circ} \mathrm{C}$ above pre-industrial levels, between 1.6 and 3.8 trillion US dollars are needed in annual energy investments alone. However, it is estimated that countries are currently spending less than half of what is needed (Alayza and Caldwell 2021).

At COP26, the G77 + China developing country caucus - negotiating for 130 nations representing $85 \%$ of the world's population - called on donor countries to mobilize at least US $\$ 1.3$ trillion yearly by 2030 . This should be equally split 50/50 between adaptation and mitigation, with at least US $\$ 100 \mathrm{bn}$ in grant funding. However, countries like Australia, Norway, and the European Union (EU) refused to settle on a firm commitment.

The compromise target was to renew the unmet 2009 climate finance pledge of US\$100bn annually within the next two years, and to double existing adaptation funding. However, the UN Environment Programme's (UNEP 2021: 30) 'highly indicative' estimate was that adaptation funds need to rise to US $\$ 250$ bn yearly by $2030 .{ }^{19}$ Further, no agreement was struck on acceptable methodologies to track adaptation finance, including definitions, accounting issues, confidentiality restrictions and impact metrics.

\footnotetext{
${ }^{19}$ For 58 developing countries that submitted updated Nationally Determined Contribution (NDC) National Adaptation Plan (NAP) to the UNFCCC up to July 2021.
}

\section{Nothing for the Worst-off}

The call by developing countries, particularly SIDS, for COP26 to create a new finance facility for $L \& D$ was pushed back by developed nations such as the US and the EU. L\&D refers to the major adverse effects of climate change, especially those that countries cannot adapt to. Poor nations have argued for decades that they should be compensated by rich countries for irreversible damage and loss due to global warming. ${ }^{20}$

L\&D was mentioned an unprecedented twelve times in the final Glasgow outcome text, but without making any firm commitments to funding or even mechanisms to secure funding. Rich countries only agreed to begin a 'dialogue' to discuss 'arrangements for the funding of activities to avert, minimize and address loss and damage'. Representing developing nations, Guinea expressed 'extreme disappointment' ${ }^{21}$ at this further delay of progress in financing vulnerable developing countries for the L\&D they have suffered due to climate disasters. ${ }^{22}$

Low-lying small island and other nations - from the Marshall Islands to Fiji and Antigua - fear losing much of their land, especially arable soils, to rising sea levels. South Pacific SIDS representatives have expressed disappointment at lack of funding for L\&D. For them, COP26 was a 'monumental failure', leaving them in existential peril. ${ }^{23}$

In sum, the Glasgow Climate Summit has failed to fix the decade-old broken climate finance promises. Headline grabbing announcements containing some vague promises have merely served to kick the can down the road to COP27 in Sharm El-Sheikh, Egypt. Meanwhile, the costs of failure keep rising, both materially and financially.

\section{Minding the Gap}

A recent assessment by the UNFCCC-SCF (2021) estimated that developing countries require US\$5.8-5.9 trillion up to 2030 to fund less than half the actions outlined in official climate plans, including those to be funded domestically. Developing countries' adaptation costs alone are projected at

\footnotetext{
${ }^{20}$ https://www.dw.com/en/loss-and-damage-cop26-climate-changesmall-island-states-finance/a-59738141 accessed 11 January 2022.

${ }^{21}$ https://www.dw.com/en/cop26-blah-blah-blah-as-world-nearsclimate-catastrophe/a-59812342 accessed 11 January 2022.

${ }^{22}$ Financial pledges from Scotland and Wallonia (Francophone southern Belgium) - $£ 2$ million (US\$2.6 million) and EUR1 million (US\$1.1 million) respectively - to address losses and damages were the first of their kind.

${ }^{23}$ https://www.theguardian.com/world/2021/nov/15/cop26-pacificdelegates-condemn-monumental-failure-that-leaves-islands-in-peril accessed 11 January 2022.
} 
US $\$ 155-330$ bn by 2030 , rising to US $\$ 310-555$ bn by 2050 'with increasing levels of climate change' (UNEP 2021: 29). ${ }^{24}$

Currently fragmented climate financing urgently needs more coherence as well as strategic prioritization of support to those most distressed and vulnerable. Developing countries expected the promised US $\$ 100$ bn yearly to be largely public grants disbursed via the then new UNFCCC GCF. Oxfam (2020) estimated public climate financing at only US\$19-22.5bn in 2017-18, noting little effective coordination of public finance.

Developing countries believed their representatives would help decide disbursement, ensuring equity, efficacy and efficiency. But little is managed by the developing countries themselves. Instead, climate finance is disbursed via many channels, including rich countries' aid and export promotion agencies, private banks, equity funds and multilateral financial institutions' loans and grants.

Several UN programmes also support climate action, including UNEP, the UN Development Programme (UNDP) and Global Environment Facility (GEF). But all are underfunded, requiring frequent replenishment. Uncertain financing and developing countries' lack of meaningful involvement in disbursements make planning more difficult.

Meanwhile, financialization has meant that climate funding increasingly involves private financial interests. Claims of private climate finance from rich to poor countries have been much contested (Roberts et al. 2021). Even OECD (2020) estimates have not been rising steadily, instead fluctuating directionless from US\$16.7bn in 2014 to US\$10.1bn in 2016 and US\$14.6bn in 2018.

The actual role and impact of private finance are also much disputed. Unsurprisingly, private funding is unlikely to help countries most in need, address policy priorities, or finance adaptation measures. Instead, 'blended finance' often uses public finance to 'de-risk' private investments.

\section{Cooperating for More Finance}

Funding developing countries' climate change mitigation and adaption efforts was never going to be easy. But it became more uncertain with President Trump's decision to renounce the PA. Three days before he was elected, the US had only contributed US\$500 mn, bringing total US contribution to US\$1bn, far short of the modest Obama pledge of US\$3bn towards the US\$10bn yearly target for the GCF - the UN's flagship climate finance initiative. ${ }^{25}$ As the largest shareholder, the US had also blocked the IMF proposal

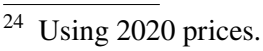

25 https://www.bbc.com/news/world-us-canada-38661259 accessed 17 January 2022.
}

to issue new Special Drawing Rights (SDRs) ${ }^{26}$ to cope with the pandemic, because that would also benefit countries the Trump Administration disliked. ${ }^{27}$

Hopes for enhanced multilateralism and improved international cooperation grew with President Biden's 'America is back' declaration. ${ }^{28}$ In April 2021, he promised US\$5.7bn, with US\$1.5bn earmarked for adaptation. However, the US role at COP26 fell far short of hopes. Based on its GNI, population size and cumulative emissions, the US should provide between US\$43bn and US\$50bn each year in climate finance. It also declined to contribute to the L\&D Fund. And to circumvent resistance from its Congress, the US only allowed a new SDR issue of US\$650bn - half the US\$1.37 trillion that The Financial Times (2020) estimated would be needed.

As emphasized earlier, even if the pledged US\$100 billion yearly finance target is achieved, it would still be inadequate to meet climate finance needs. The World Future Council (WFC) estimates that annual global investments of US\$2 trillion are needed to have a chance of keeping the temperature rise below $1.5^{\circ} \mathrm{C}$. Obviously, the task is daunting, especially for developing countries more vulnerable to climate change.

In adopting the Marrakech Vision at the 2016 COP22 to achieve $100 \%$ domestic renewable energy production as rapidly as possible, 48 members of the Climate Vulnerable Forum advocated for an 'international cooperative system' for 'attaining a significant increase in climate investment in [...] public and private climate finance from wide ranging sources, including international, regional and domestic mobilization'. ${ }^{29}$

International cooperation is necessary, considering developing countries' limited abilities to mobilize enough finance. Significant foreign funds are needed to import needed green technologies. Also, most renewable energy investments needed in developing countries will not be profitable enough to attract private investment, including foreign direct investment.

Hence, the UN, IMF and others have suggested using SDRs, while the WFC has proposed that developed

\footnotetext{
${ }^{26}$ The SDR is an international reserve asset, created by the IMF in 1969 to supplement member countries' official reserves. To date, a total of SDR660.7bn (about US\$943bn) have been allocated, which includes the most recent allocation. The value of the SDR is based on a basket of five currencies-the US dollar, euro, Chinese renminbi, Japanese yen, and British pound sterling.

${ }^{27}$ Reuters, U.S. stalling massive IMF liquidity boost over Iran, China: sources. 15 April 2020. https://www.reuters.com/article/usimf-worldbank-sdrs-idUSKCN21X0L8 accessed 29 December 2021.

${ }^{28}$ https://www.youtube.com/watch?v=SYuQekIL_CI accessed 13 January 2022.

29 https://www.worldfuturecouncil.org/financing-100-re-in-cvf-count ries/ accessed 12 January 2022.
} 
countries' central banks use quantitative easing (QE) to enhance climate finance. Others have argued for debt relief, especially due to the unprecedented rise in debt responding to the pandemic.

\section{Special Drawing Rights}

The UN has been advocating issuing SDRs to create more development finance since the mid-1960s when SDRs were first proposed. However, rich countries are largely opposed, arguing this would distort the purpose for which SDRs were first created, i.e., to supplement foreign exchange reserve assets. Also, leveraging SDRs for more development finance would expose bond holders to liquidity risks.

The latest UN proposal to use SDRs for development finance was made in 2012 after the IMF issued SDRs to support recovery from the 2008-09 global financial crisis (United Nations 2012). It estimated that regular SDR allocations and redeployment of 'idle' developed country SDRs could yield about US $\$ 100 \mathrm{bn}$ yearly to purchase long-term assets which could then be used for development finance. The proposal involved floating bonds backed by SDRs, rather than directly spending SDRs. Thus, for example, the GCF could issue US $\$ 1 \mathrm{tn}$ in bonds, backed by US $\$ 100 \mathrm{bn}$ in SDR equity.

Opposition to the UN proposal should be reduced by only leveraging 'idle' SDRs held by reserve-rich countries to purchase such bonds (Chowdhury and Jomo 2017). This would be comparable to countries investing foreign currency reserves through sovereign wealth funds, where the liquidity and risk characteristics of specific assets in the funds determine whether they qualify as reserve holdings. Thus, by maintaining their reserve function, careful design in leveraging SDRs can reduce objections. This more modest and less ambitious proposal should face less political resistance from developed countries as it delinks the SDR allocation formula from the debate over amending IMF quotas.

The IMF is proposing a Resilience and Sustainability Trust (RST), aimed at helping countries build resilience, respond to climate change and accelerate transitions supportive of both development and climate. With the proper modalities, including regular replenishment, and without onerous conditionalities increasing member country debt burdens, such a facility would also strengthen the climate finance architecture.

The proposed RST will be initially financed by 're-channelling' unused allocations from the recent US\$650bn in SDRs approved by the IMF in August 2021. The 2021 SDR allocation was the largest in history, but most SDRs would go to high-income countries (HICs). Just over $1 \%$ of SDR allocations would go to the poorest countries, according to the Task Force on Climate, Development, and the IMF (TFCD \& IMF 2021). HICs not facing foreign exchange shortage would have little need to deploy their allocated SDRs, not even to finance budget deficits.

Because of the current SDR allocation system based on countries' quota or automatic borrowing rights, within the IMF - quota formula heavily dependent on countries' aggregate GDP - barely $3 \%$ of new SDRs went to LICs, $30 \%$ to middle-income emerging market economies, nearly $60 \%$ to HICs, and more than $17 \%$ to the US, which can virtually print dollars at will (Eichengreen 2021). Therefore, several leading economists (Bradlow and Gallagher 2021; Gallagher and Ocampo 2021; Eichengreen 2021) have suggested new SDR allocation rules, including re-channelling unused SDRs from HICs to special funds at the IMF and multilateral and regional development banks, designated as 'prescribed' SDR institutions, for COVID-19 recovery, especially in LICs.

But the prospect of changing SDR allocation rules to support development is bleak. ${ }^{30}$ Meanwhile, G7 leaders only called upon other countries for contributions in support of their 'aim to reach a total global ambition' of [US] $\$ 100$ billion of voluntarily re-channelled SDRs to help LICs deal with the pandemic and achieve green recovery. ${ }^{31}$ This socalled 'global ambition' is miniscule compared with the US\$17 trillion that rich countries have spent to support their economies during the pandemic. The finance required to support decarbonization in the developing world and to foster climate resilience is far greater than the US\$650bn SDRs approved in response to the pandemic. But it is nonetheless significant, especially to signal global solidarity and promote international cooperation.

\footnotetext{
${ }^{30}$ Ever since SDRs were first conceived in the 1960s, it has been suggested that SDRs be issued for use as development finance. In 1965, a group of experts working for UNCTAD argued that SDRs should be allocated to meet the development finance needs of newly independent countries. But when SDRs were issued in 1970, they were instead allocated in proportion to IMF members' quotas. Following the 1971 US withdrawal from its Bretton Woods commitment to fixed gold convertibility of the US dollar, in 1972-73, developing countries proposed what came to be known as 'the link'. They envisaged a 'deal' in which the (mainly European) developed countries would get a reformed international monetary system, in which the SDR would serve as the international reserve currency - just as the US dollar had done in the by then defunct Bretton Woods system, thus eliminating the US dollar's 'exorbitant privilege'. In return for their support, developing countries should receive most of the next SDR allocation. In the end, a second SDR allocation went ahead, but developing countries were promised that their proposal might be considered in future. But nothing has been done for the link since. Support for issuing SDRs for development finance resurfaced to finance the Millennium Development Goals, but again, nothing happened. Later, 250bn SDRs were issued in 2009 in response to the GFC, again allocated according to member quotas.

31 https://www.whitehouse.gov/briefing-room/statements-releases/ 2021/06/13/carbis-bay-g7-summit-communique/ accessed 12 January 2022.
} 
However, the RST must be well-designed to effectively utilize re-channelled SDRs. Observers have already expressed concerns about onerous conditionalities, eligibility criteria to access the RST, and the IMF proposal to charge interest (currently five basis points and on the rise) on SDRs plus a margin of up to 100 basis points (Ahmed et al. 2021; TFCD \& IMF 2021). These rates are not very different from what the Fund currently charges middle-income countries (MICs). More problematic are the access limits, which would be $100 \%$ of quota, or less than the SDR equivalent of US\$1bn. According to Ahmed et al. (2021), 'These guidelines would do little to address the financing needs of all but the smallest countries'.

As emphasized by TFCD \& IMF (2021), modalities must ensure truly concessional financing and credit risk bearing, as with the IMF's Poverty Reduction and Growth Trust. Also, eligibility for low-cost finance should be broad enough to include climate vulnerable MICs, especially those lacking the fiscal space to address climate shocks or invest in resilience and low carbon transitions. The TFCD \& IMF proposed that an RST should have three overarching climate objectives:

1. Enhance country capacity to respond to climate shocks without significantly increasing debt burdens.

2. Catalyze low-cost financing and capacity building for poorer, climate vulnerable countries to strengthen climate resilience and adaptation strategies.

3. Enhance the ability of emerging market economies and developing countries to mobilize longer-term financing for just transitions to low carbon growth pathways.

Opportunities for climate-related aspects of RST should include:

- Short-term financing to respond to climate shocks

- Longer-term financing for capacity building, resilience, adaptation and just transitions

- Broadening eligibility for and sustainability of RST

It should be noted that the new SDRs were primarily issued to enhance international liquidity to strengthen responses to the pandemic. Thus, most discussions about their use relate to supporting LICs' COVID recovery efforts. Nonetheless, well-designed recovery plans and effective coordination between fiscal and monetary authorities can accelerate green structural transformation (Chowdhury and Jomo 2021a, 2021b).

\section{Quantitative Easing}

The WFC has proposed that central banks of developed countries continue 'quantitative easing' (QE), but not buy existing financial assets. Instead, they should invest in 'Green Climate Bonds' (GCBs) issued by MDBs, the GCF or some other designated climate finance institution to fund renewable energy projects in developing countries.

This should have some other benefits. First, it will not destabilize the financial systems of emerging economies, whereas QE since the 2008-09 global financial crisis has fueled speculation and asset price bubbles. Second, it is unlikely to increase inflation, except perhaps temporarily, as it will be used for productive investments. Third, it follows that such QE should not exacerbate inequality.

Fourth, it will also help industrial countries as developing countries receiving climate finance will import technology and related services from developed economies, and hence should result in more balanced development globally. Fifth, GCBs can become near permanent assets of central banks due to their long duration.

\section{Debt Relief}

The debt burdens of LMICs have been exacerbated by the COVID-19 pandemic, ensuring limited fiscal responses, delaying economic recovery, as well as climate mitigation and adaptation measures. Before the pandemic, developing countries were spending $30-70 \%$ of their revenue on debt servicing in 2019 (Picolotti and Miller 2020). The debt burden of the least developed countries (LDCs) alone reached a record US\$744bn (World Bank 2020). The high costs of COVID-19 responses and revenue losses have pushed many countries even deeper into debt (Steele and Patel 2020).

Poorer countries spent five times more on debt than on climate action (Jubilee Debt Campaign 2021). Climate change impacts exacerbate development challenges, increasing loan and aid dependence (Picolotti and Miller 2020). With declining aid in the form of grants, developing countries, especially MICs, face a cruel dilemma, having to choose between increased climate indebtedness and inaction.

Thus, in addition to calls for more generous, e.g., grantbased climate finance, civil society SDG advocates - e.g., Jubilee Debt Campaign, Oxfam, International Institute for Environment and Development (IIED) - have called for more meaningful debt relief and debt swaps for climate actions. In the past, debt swaps - such as the IMF-World Bank Highly Indebted Poor Countries (HIPC) initiative, launched in 1996 - were conditional on showing debt relief had contributed to the Millennium Development Goals, particularly the education goal (Ondoa 2018).

While the IMF's swift action to cancel US\$250 million in debt of the most vulnerable LICs has been welcome, the World Bank has refused to do likewise, arguing it would adversely impact its credit rating. The G20 countries' Debt Service Suspension Initiative (DSSI) has been mean-spirited, only postponing debt repayment, to be fully paid later 
with accumulated interest. Moreover, private creditors have not joined the G20 initiative, despite appeals by G20 leaders. Increased solidarity of developing countries - especially LICs and LDCs - is vital, especially in maintaining pressure for meaningful debt relief and debt swaps for climate actions.

\section{Concluding Remarks}

The world faces a climate finance conundrum owing to the failure to resolve the underlying issues equitably through international cooperation. Consequently, it would not be an exaggeration to describe the current situation as a mess. Various climate finance arrangements have been developed over recent decades, but they have clearly failed to rise to the challenges faced. There is little disagreement that international public finance for this purpose has been grossly inadequate. In 2009, various European leaders pledged US $\$ 100 \mathrm{bn}$ annually in climate finance, but rich countries have failed to deliver on these promises made over a dozen years ago.

Other improvements are also needed if climate finance arrangements are going to be more supportive of equitable climate actions, i.e., thus advancing climate justice.

Rich developed countries have tended to focus on the COPs hosted by them as most significant. Hence, they have tended to mobilize most for such COPs, hosted in Copenhagen in 2009, Paris in 2015 and Glasgow in 2021. US unwillingness to 'seal the deal' during the incumbent president's first term ensured Copenhagen's failure, but also the modest breakthrough at Paris six years later, reversed barely two years later by President Trump. Hence, expectations were high before Glasgow, encouraged by the UK Prime Minister's over-the-top rhetoric which the erstwhile Trump ally failed to deliver on.

However, there is now little disagreement that the Glasgow COP proved to be a catastrophic failure. The injustice of various climate-related arrangements is self-evident, as private profits are prioritized over the future of the planet and humanity itself. The subterfuge is growing with ostensibly massive purported financial investments added to the mix despite the well-known disappointments associated with financialization. International financial institutions, including the MDBs, have failed to rise to the challenges of climate finance. So, a dozen years after the Copenhagen COP, Glasgow merely reiterated its grossly inadequate promise of US \$100bn annually, now elaborated even more ambiguously to possibly include all manner of private investments. The Glasgow COP also managed to kick the can down the road for climate's worst-off victims to be 'compensated' for the losses and damages they have suffered.

Finally, several pragmatic proposals are offered to address the massive climate finance gap. As sovereign debt relief has been much discussed elsewhere, the two main suggestions draw upon policy initiatives already embraced by rich countries in recent years. Since the 2008 global financial crisis, many rich countries have embraced unconventional monetary policies, especially quantitative easing. These need to be reconsidered for the variety of developing countries, but especially by rich countries to sustainably finance urgently needed climate action, especially for adaptation to global warming's evolving consequences. IMF allocation of SDRs should also be reconsidered to better fill foreign exchange needs required for sustainable international climate action.

Worsening climate change needs to be urgently checked through enhanced mitigation efforts such as accelerating the transition to renewable energy sources. But developing countries also desperately need help to cope with effects of global warming thus far through appropriate adaptation efforts. The most vulnerable also need to be compensated for the irreversible harm they have experienced to enable them to better cope with their predicament. But existing proposals have clearly failed to rise to the huge climate finance, the world, especially developing countries, face. Hence, it is necessary, even obligatory to think out of the box and to consider novel policy proposals, which are in fact quite familiar in terms of recent international experience.

\section{References}

Ahmed, Sara Jane, Alicia Bárcena, and Daniel Titelman. 2021. IMF misstep on climate finance. The Asset: Green Finance/Viewpoint, 14 December. https://mag.theasset.com/article-esg/45666/imfmisstep-on-climate-finance accessed 12 January 2022.

Alayza, Natalia, and Molly Caldwell. 2021. Financing climate action and the COVID-19 pandemic: An analysis of 17 developing countries. World Resources Institute working paper. https://www.wri. org/research/financing-climate-action-and-covid-19-pandemic accessed 13 January 2022.

Baker, Jill. 2021. Mark Carney's ambitious \$130 trillion glasgow financial alliance for net-zero. Forbes, 8 November. https://www.forbes. com/sites/jillbaker/2021/11/08/mark-carneys-ambitious-130-trill ion-glasgow-financial-alliance-for-net-zero/?sh $=4 \mathrm{~b} 628 \mathrm{ffc} 3 \mathrm{a} 31$ accessed 11 January 2022.

Bassetti, Francesco. 2019. The cruel irony of climate debt. Foresight: the CMCC observatory on climate policies and futures, 29 October. https://www.climateforesight.eu/migrations-inequalities/thecruel-irony-of-climate-debt/ accessed 12 January 2022.

Bos, Julie, and Joe Thwaites. 2021. A breakdown of developed countries' public climate finance contributions towards the $\$ 100$ billion goal. https://files.wri.org/d8/s3fs-public/2021-10/breakdowndeveloped-countries-public-climate-finance-contributions-towar ds-100-billion.pdf? accessed 11 January 2022.

Bradlow, Daniel, and Kevin Gallagher. 2021. Making \$650B in SDRs work for lower-income countries. Devex blog, 17 August. https:// www.devex.com/news/opinion-making-650b-in-sdrs-work-forlower-income-countries-100546 accessed 30 December 2021.

Chowdhury, Anis, and K.S. Jomo. 2017. Scaling up Development Finance. Inter Press Service (IPS) News Agency, 5 September. http://www.ipsnews.net/2017/09/scaling-development-finance/ accessed 13 January 2022. 
Chowdhury, Anis, and K.S. Jomo. 2021a. Central Banks Must Address Pandemic Challenges. Inter Press Service (IPS) News Agency, 3 August. https://www.ipsnews.net/wp-content/cache/ all/2021a/08/central-banks-must-address-pandemic-challenges/ index.html accessed 13 January 2022.

Chowdhury, Anis, and K.S. Jomo. 2021b. Boldly finance recovery to build forward better. Inter Press Service (IPS) News Agency, 22 June. https://www.ipsnews.net/2021b/06/boldly-finance-recov ery-build-forward-better/ accessed 13 January 2022.

Clarke, Joe, and Luke Barratt. 2021. Top airlines' promises to offset flights rely on 'phantom credits'. Unearthed, 4 May. https:// unearthed.greenpeace.org/2021/05/04/carbon-offsetting-briti sh-airways-easyjet-verra/ accessed 12 January 2022.

Colenbrander, Sarah, Cao, Yue, Laetitia Pettinotti, and Adriana Quevedo. 2021. A fair share of climate finance? Apportioning responsibility for the $\$ 100$ billion climate finance goal. Overseas Development Institute working paper, 6 September. https:// odi.org/en/publications/a-fair-share-of-climate-finance-appor tioning-responsibility-for-the-100-billion-climate-finance-goal/ accessed 17 January 2022.

The Economist. 2020. Cheap cheats: Why are carbon markets so cheap? The Economist, 19 September. https://www.economist. com/special-report/2020/09/17/cheap-cheats accessed 12 January 2022

Edgecliffe-Johnson, Andrew, and Peggy Hollinger. 2021. Businesses rally behind global carbon pricing strategy. Financial Review, 28 October, https://www.afr.com/policy/energy-and-climate/busin esses-rally-behind-global-carbon-pricing-strategy-20211028p59431 accessed 12 January 2022.

Eichengreen, Barry 2021. This SDR allocation must be different. Project Syndicate. https://www.project-syndicate.org/commentary/ how-to-get-new-imf-sdrs-to-poor-countries-by-barry-eichengreen2021-09 accessed 13 January 2022.

Elgin, Ben. 2020. These trees are not what they seem: How the nature conservancy, the world's biggest environmental group, became a dealer of meaningless carbon offsets. Bloomberg Green, 9 December. https://www.bloomberg.com/features/2020-nature-conse rvancy-carbon-offsets-trees/ accessed 12 January 2022.

Fink, Larry. 2021. Rich countries must bear the cost if we can ever hope to achieve a net-zero world. The New York Times, 13 October. https://www.nytimes.com/2021/10/13/opinion/climatechange-imf-carbon.html accessed 11 January 2021.

Gallagher, Kevin, and Jose Antonio Ocampo. 2021. Making the most of a new SDR ration. https://www.reuters.com/article/us-imf-sdrbreakingviews-idUSKBN2BU1ZM accessed 29 December 2021.

IMF. 2017. World economic outlook october 2017 - seeking sustainable growth: Short-term recovery, long-term challenges. Washington, DC: International Monetary Fund.

TFCD \& IMF. 2021. Making special drawing rights work for climate action and development. Task force on climate-related financial disclosures (TFCD) and international monetary fund. OECD development matters. https://oecd-development-matters.org/2021/ 10/07/making-special-drawing-rights-work-for-climate-actionand-development/ accessed 12 January 2022.

InfluenceMap. 2019. Big oil's real agenda on climate change: An influencemap report. https://influencemap.org/report/How-Big-OilContinues-to-Oppose-the-Paris-Agreement-38212275958aa21 196dae3b76220bddc accessed 12 January 2022.

Johnson, Zoe, and Maura Wests. 2021. Outcomes of COP26 - and what they mean for climate finance advocacy. Donor Tracker Commentary, 24 November, https://donortracker.org/insights/outcomescop26-and-what-they-mean-climate-finance-advocacy accessed 11 January 2022.

Jubilee Debt Campaign. 2021. Lower income countries spend five times more on debt payments than dealing with climate change. October. https://jubileedebt.org.uk/wp-content/uploads/2021/
10/Lower-income-countries-spending-on-adaptation_10.21.pdf accessed 13 January 2022.

Larsen, Gaia, Caitlin Smith, Nisha Krishnan, Lutz Weischer, Sophie Bartosch and Hanna Fekete. 2018. Towards Paris alignment: How the multilateral development banks can better support the paris agreement. World Resources Institute, Washington, DC. https://files.wri.org/d8/s3fs-public/toward-paris-alignment_1.pdf accessed 12 January 2022.

Mason, Jeff, Andrea Shalal, and Emma Rumney. 2021. South Africa to get $\$ 8.5$ bln from U.S., EU and UK to speed up shift from coal. Reuters report, 3 November. https://www.reuters.com/business/ environment/us-eu-others-will-invest-speed-safricas-transitionclean-energy-biden-2021-11-02/ accessed 11 January 2021.

McCandless, Brad, Carolyn Neunuebel, Shaung Liu, Valerie Laxton, Aki Kachi, and Anja Gebel. 2021. MDBs pledged to align financial flows with the paris agreement. They're Not There Yet. World Resources Institute blog, 1 November, https://www.wri.org/insig hts/mdbs-pledged-align-financial-flows-paris-agreement-theyrenot-there-yet accessed 12 January 2022.

Mitchell, Ian 2021. Climate finance is the elephant in the room at COP26. Chatham House blog, 5 November. https://www.chath amhouse.org/2021/11/climate-finance-elephant-room-cop26 accessed 11 January 2021.

OECD. 2021. Climate finance provided and mobilised by developed countries: Aggregate trends updated with 2019 data. Paris: Organization for Economic Cooperation and Development.

OECD. 2020. Climate finance provided and mobilised by developed countries in 2013-18: Key highlights. https://www.oecd.org/envir onment/cc/Key-Highlights-Climate-Finance-Provided-and-Mobil ised-by-Developed-Countries-in-2013-18.pdf accessed 12 January 2022.

Ondoa, Henri A. 2018. The effects of heavily indebted poor countries initiative (HIPC) on millennium development goals (MDGs) for education. Review of Social Economy 76 (4): 453-479.

Oxfam. 2020. Climate finance shadow report 2020: Assessing progress towards the $\$ 100$ billion commitment. Oxfam, Oxford. https:// oxfamilibrary.openrepository.com/bitstream/handle/10546/ 621066/bp-climate-finance-shadow-report-2020-201020-en.pdf accessed 12 January 2022.

Oxfam. 2021. Poorer Nations Expected to Face up to $£ 55$ billion Shortfall in Climate Finance. Press Release, 20 September. https:// www.oxfam.org.uk/media/press-releases/poorer-nations-expec ted-to-face-up-to-55-billion-shortfall-in-climate-finance/ accessed 11 January 2022.

Picolotti, Romina, and Alan Miller. 2020. Debt-for-climate swaps can help developing countries make a green recovery. Climate Home News, 5 November. https://www.climatechangenews.com/2020/ 11/05/debt-climate-swaps-can-help-developing-countries-makegreen-recovery/ accessed 13 January 2022.

Climate policy initiative. 2021. Global landscape of climate finance 2021. https://www.climatepolicyinitiative.org/wp-content/uploa ds/2021/10/Full-report-Global-Landscape-of-Climate-Finance2021.pdf (11/01/2022)

Roberts, J. Timmons, Romain Weikmans, Stacy-Ann Robinson, David Ciplet, Mizan Khan, and Danielle Falzon. 2021. Rebooting a failed promise of climate finance. Nature Climate Change 11 (March): 180-182.

Spring, Jake, and Kate Abnett. 2021. U.N. climate summit reaches carbon markets deal. Reuters, 14 November. https://www.reuters. com/business/cop/outline-carbon-markets-deal-emerges-un-clima te-summit-2021-11-13/ accessed 12 January 2022.

Steele, Paul, and Sejal Patel 2020. Tackling the triple crisis: Using debt swaps to address debt, climate and nature loss post-COVID-19. International Institute for Environment and Development (IIED) issue paper. September. https://pubs.iied.org/sites/default/files/ pdfs/migrate/16674IIED.pdf accessed 13 January 2022. 
Financial Times. 2020. New issuance of SDRs is vital to help poorer countries. The Financial Times, 12 April. https://www.ft.com/ content/2691bfa2-799e-11ea-af44-daa3def9ae03 accessed 13 January 2022.

Tonkonogy, Bella. 2021. 5 Climate finance themes that emerged from COP26. Climate policy initiative blog, 16 November, https:// www.climatepolicyinitiative.org/5-climate-finance-themes-thatemerged-from-cop26/ accessed 11 January 2022.

UNCTAD. 2021. Trade and development report 2021: From recovery to resilience - the development dimension. Geneva \& New York: The United Nations.

UNEP. 2021. Adaptation gap report 2021: The gathering storm - adapting to climate change in a post-pandemic world. Nairobi: UN Environment Programme.

UNFCCC-SCF. 2014. UNFCCC standing committee on finance 2014 biennial assessment and overview of climate finance flows report. https://unfccc.int/files/cooperation_and_support/financial_mecha nism/standing_committee/application/pdf/2014_biennial_asses sment_and_overview_of_climate_finance_flows_report_web. pdf accessed 11 January 2022.

UNFCCC-SCF. 2021. UNFCCC standing committee on finance: first report on the determination of the needs of developing country parties related to implementing the convention and the Paris agreement. https://unfccc.int/sites/default/files/resource/ 54307_2\%20-\%20UNFCCC\%20First\%20NDR\%20technical\% 20report\%20-\%20web\%20\%28004\%29.pdf accessed 11 January 2022.

UN-IEGCF. 2020. Delivering on the $\$ 100$ billion climate finance commitment and transforming climate finance. https://www.un.org/ sites/un2.un.org/files/100_billion_climate_finance_report.pdf $(11 / 01 / 2022)$

United Nations. 2012. World economic situation and prospects 2012. New York: The United Nations.

Weikmans, Romian, and Timmons Roberts. 2019. The international climate finance accounting muddle: Is there hope on the horizon? Climate and Development 11 (2): 97-111.

World Bank. 2021. State and trends of carbon pricing 2021. Washington, DC: The World Bank.

World Bank. 2020. Debt burden of least developed countries continues to climb to a record $\$ 744$ billion in 2019. Press Release, 12 October. https://www.worldbank.org/en/news/press-release/2020/10/ 12/debt-burden-of-least-developed-countries-continues-to-climbto-a-record-744-billion-in-2019 accessed 13 January 2022.

Publisher's Note Springer Nature remains neutral with regard to jurisdictional claims in published maps and institutional affiliations. 